\title{
Marisa Verna, Vers un art total
}

\section{Ida Merello}

\section{(2) OpenEdition}

\section{Journals}

\section{Edizione digitale}

URL: http://journals.openedition.org/studifrancesi/27927

DOI: 10.4000/studifrancesi.27927

ISSN: 2427-5856

\section{Editore}

Rosenberg \& Sellier

\section{Edizione cartacea}

Data di pubblicazione: 31 décembre 2006

Paginazione: 633

ISSN: 0039-2944

\section{Notizia bibliografica digitale}

Ida Merello, « Marisa Verna, Vers un art total », Studi Francesi [Online], 150 (L | III) | 2006, online dal 30 novembre 2015, consultato il 08 novembre 2020. URL : http://journals.openedition.org/studifrancesi/ 27927 ; DOI : https://doi.org/10.4000/studifrancesi.27927

\section{Questo documento è stato generato automaticamente il 8 novembre 2020.}

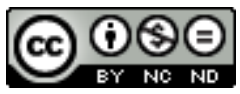

Studi Francesi è distribuita con Licenza Creative Commons Attribuzione - Non commerciale - Non opere derivate 4.0 Internazionale. 
Marisa Verna, Vers un art total

Ida Merello 


\section{NOTIZIA}

MARISA VERNA, Vers un art total, «Revue d'histoire du théâtre», n²28, IV-2005, pp.

307-332.

L'A. studia la collaborazione tra i pittori Nabis e i drammaturghi simbolisti al Théâtre d'Art di Paul Fort, confrontando le teorie estetiche di pittori e letterati e tentando di rintracciarne i modelli. Se è vero che il Théâtre d'Art mostra di voler aderire intimamente ai principi mallarmeani dell'estetica drammatica -come risulta dalle dichiarazioni di Charles Morice, il teorico del gruppo-, l'A. individua in Baudelaire uno dei primi riferimenti di quella sorta di manifesto del Théâtre che usci su «L'Echo de Paris» del 30 gennaio 1891. L'idea di sinestesia teatrale risale infatti alla lettura baudelairiana di Wagner, con l'affermazione dell'oggettività intersensoriale e lo spostamento del fenomeno sinestesico dal livello della creazione a quello della ricezione artistica. L'A. ricorda uno dei primi tentativi, la messa in scena del Cantico dei Cantici nel dicembre 91, in cui il testo era stato suddiviso in stanze di colori toni e profumi diversi, che fallì per la mancanza di proiettori e vaporizzatori adeguati. Tale iniziativa promosse comunque una sperimentazione sinestesica inedita e la creazione di nuovi décors. L'amicizia tra Maurice Denis e Lugné-Poe portò i Nabis a interessarsi vivamente a queste esperienze : la collaborazione ebbe inizio con La Fille aux mains coupées di Pierre Quillard, con uno sfondo di Sérusier, non inteso appunto come tale, bensì come integrazione della parola. Le teorie estetiche di Denis (predominio della forma sul contenuto, bellezza fondata su rapporti formali, spiritualità dell'arte), come quelle assai prossime di Emile Bernard (predominio della forma sul contenuto, semplificazione, sintetismo, rapporto poesia-letteratura) mostrano una grande consonanza con quelle dei poeti contemporanei in relazione alle idee sull'arte totale, sulla natura artificiale dell'arte, pura forma contraria alla mimesi, in nome del recupero di una più ampia armonia mistica universale. 